DOI: https://doi.org/10.34069/AI/2021.44.08.15

How to Cite:

Yeremenko, H.Yu., Yakovleva, S.D., \& Sagan, O.V. (2021). The state of creativity in adolescents with intellectual disabilities. Amazonia Investiga, 10(44), 160-167. https://doi.org/10.34069/AI/2021.44.08.15

\title{
The state of creativity in adolescents with intellectual disabilities
}

\section{Стан креативності підлітків з порушенням інтелектуального розвитку}

Received: May 21, 2021

\begin{abstract}
The objective of the article is to investigate empirically and substantiate theoretically the state of creativity in adolescents with intellectual disabilities; to reveal gender differences and changes in creativity during puberty in 13-15year old adolescents.

Davis's standardized technique was used to determine the respondents' creativity. Obtained data were processed using Student's t-test for paired samples. The obtained results showed existing but not realized capabilities of adolescents with intellectual disabilities, so special correctional and developmental work should be performed with them.
\end{abstract}

Keywords: creativity, adolescents, intellectual disabilities, gender.

\section{Introduction}

The current revival of Ukrainian society is characterized by the need in creative thinking people, so the way for their successful development should be find. People's creativity depends on people' activities and conditions created for the development of every individual, so the development of pupils' creative abilities becomes socially important.

A creative personality can be characterized via their abilities, motives, knowledge and skills, thanks to which they can create new, original and
Accepted: July 30, 2021

$$
\begin{array}{r}
\text { Written by: } \\
\text { Yeremenko H.Yuu. } \\
\text { ss } \\
\text { https://orcid.org/0000-0003-0009-2913 } \\
\text { Yakovleva S.D. }{ }^{59} \\
\text { https://orcid.org/0000-0001-7620-098X } \\
\text { Sagan O.V. }{ }^{60} \\
\text { https://orcid.org/0000-0002-3195-3686 }
\end{array}
$$

\begin{abstract}
Анотація
Метою статті є емпіричне дослідження та теоретичне обгрунтування стану творчості підлітків 3 вадами розумового розвитку; виявити гендерні відмінності та зміни у творчості під час статевого дозрівання у підлітків 13-15 років. Стандартна методика Девіса була використана для визначення рівня творчості респондентів. Отримані дані обробляли за допомогою t-критерію Стьюдента для парних зразків. Отримані результати показали наявні, але не реалізовані можливості підлітків 3 вадами розумового розвитку, тому 3 ними слід проводити спеціальну корекційно розвивальну роботу.
\end{abstract}

Ключові слова: креативність, підлітки, порушення інтелектуального розвитку, гендерні ознаки.

unique products. An individual's intuition, unconscious components of their mental activity, as well as self-actualization pay an important role in creative potential revealing and expanding.

Mental activity is based on sensory cognition, while thinking reflects reality more deeply and accurately.

The development of creative abilities is reflected in the works of national psychologists, such as Karpenko L.A., Petrovsky A.V.,

\footnotetext{
${ }^{58}$ Assistant, postgraduate, Kherson State University, Ukraine.

${ }^{59}$ Doctor in Psychological Sciences, Kherson State University, Ukraine.

${ }^{60}$ Docent, $\mathrm{PhD}$, Kherson State University, Ukraine.
} 


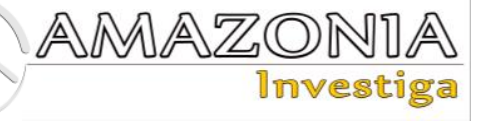

Yaroshevsky M.G. (1985), Gracham F.K., (1997), Turinina O.I. (2007), Kondratieva N.V. (2015), Kunakh G.I. (2016), Sternberg R. (2002), Guilford J. P. (1967), Torrance E. (1965), Davis (1969) and other foreign researchers made a significant contribution to the issue on creativity.

The performed theoretical analysis of prominent national and foreign scientists' works and our examination of approaches used to study creativity of children with intellectual disabilities, allowed us to identify three main creativity components:

- divergent-convergent;

- motivational-behavioural;

- personal-social.

The pedagogical encyclopedia interprets creativity as the highest form of human activities and as a specific activity. Creativity is evaluated by its social significance and novelty. In this work, we estimate formed creativity of adolescents with intellectual disorders. We investigate specific changes in creativity in adolescents with moderate intellectual disabilities to propose a set of correctional and developmental measures to better develop their creativity.

Hypothesis: Creativity of adolescence with intellectual disorders depends on their age and gender and influenced by special correctional and developmental activities.

\section{Theoretical Framework or Literature Review}

Initially, creativity as a process was seen as artists' or scientists' self-observation. Thus, studying the specific mental regulation of a creative process, Stanislavsky K.S. (1915) considered the super-consciousness as the highest concentration of an individual's spiritual forces during creativity product generation.

Creativity as a "synthetic product" is a necessary condition for personality development, especially if high cognitive motivation exists. At the same time, having high intelligence is not the same as having high creativity. Not the process of creative work, but its components, i.e. creative qualities, including imagery, high associativity, developed imagination, fantasy, the ability to generate ideas, etc., determine the creative abilities (Khutorskoy, 2003).

The concept of "creativity" means a universal ability to creative acts and creativity is characterized by certain abilities, including a psychophysiological component and an individual's mental inclinations (Rusalov, Golubeva, 1980), on the one hand, and an individual's activities (Leontiev, 1975), from the other one. There are two levels of creative abilities: reproductive (high skilfulness) and namely creativity (ability to create something new).

Because creativity is an exploratory activity, it is associated with behavioural reactions physiologically linked with the hippocampus, with emotions, i.e. structures of the limbic system, as well as with the ability to reflect objects and phenomena of the real world. It is necessary also to take into account that the organization of brain activity depends on a dominant type of thinking (abstract-logical thinking is supported by the left hemisphere and spatial-image thinking is supported by the right hemisphere).

The theoretical source lying in thinking types differentiation is the principle of unity of the psyche and activities. A human activity determines the peculiarities of mental phenomena organization. Different thinking types exist due to, primarily, the specific of an activity and the mental specifics of an individual's particular qualities at different stages of their development.

The first signal system is applied when the reality is reflected (Pavlov, 1951), the first signal system means impressions, feelings and ideas on the environment, both natural and social, but it excludes audible or visible words. The second signal system is new, namely human system that uses various symbolic means, including musical sounds, drawings, artistic images, generalized concepts.

Conceptual thinking is an integral form of mental activity. All mental functions, an individuals' cognitive experience and, first of all, figurative, sensory impressions take part in concept formation.

Kholodnaya M.A. (2002) identified specific functions of images in conceptual thinking:

- images allow an individual to combine knowledge received from the outside, through verbal signs, with one's own individual experience obtained during interactions with the world around;

- figurati ve components existing in thinking dramatically accelerates its course; 
- due to images, conceptual thinking is saturated with emotions and feelings, i.e. it becomes passionate;

- images give opportunities to make unexpected generalizations, to evoke original associations, thus, thinking receives features of a creative process.

J. Guilford (1967), based on the classical division of thinking into inductive and deductive, expressed the idea on two thinking types: convergent and divergent. He took into account that associations runs according to the objective laws of logic, therefore thinking was divided into two types depending on used mental operations: convergence and divergence. According to his ideas, inductive and deductive operations characterizes convergent thinking, which is consistent, logical, unidirectional and provides a problem solution by finding only one necessary property that meets the problem conditions and requirements. Convergent thinking is aimed at obtaining results by restoring in memory of earlier acquired knowledge. It does not imply those fantastic jumps that are necessary to reveal new knowledge. Using convergent thinking, an individual does not realize all their thinking abilities. Convergent thinking strives to achieve a single correct result. It is based on knowledge. The truth criterion for this thinking is set from the outside. The main mechanism of such thinking is logical operations (analysis, synthesis).

Divergent thinking is thinking that goes in different directions, involves a plurality of equally correct options for problem solving. Such thinking is based on intuition. Its main criterion is originality; associations, emotional factors are its psychological mechanism. These mechanisms exist as subconscious processes.

The main characteristic of divergent thinking is creativity, which means the ability to generate new, unusual ideas. Various people have creativity of various degrees. There are the following indicators describing creativity:

1. Speed means a number of ideas that an individual is able to produce per unit time.

2. Originality means rarity of ideas, how much an idea differs from generally accepted standards.

3. Flexibility means easiness of transition from one idea to another.

4. Susceptibility means sensitivity to details, nuances, paradoxes.

5. Metaphoricity means an ability to transfer one object's (phenomenon's) properties to another because of a feature common to the two compared objects.

There are also additional creativity components: systematic and consistent thinking; dialectics; willingness to take risks and responsibility for a made decision.

There is no directly proportional relationship between the indicators of convergent and divergent thinking. Convergent thinking is examined with intellectual tests measuring an IQ (mental giftedness). Creative thinking is based on a synthesis of logical thinking and imagination. These processes are not mutually exclusive, but complementary, but their role is different at different stages of a creative process.

That is, creative (or productive) thinking is understood as thinking based on creative imagination, which is manifested in constructed images of new products or developed programs for behaviour in uncertain problem situation.

Considering that J. Guilford's theory (1967) of an intelligence structure was not sufficiently substantiated, R. Sternberg (2002) proposed his own understanding of creative processes. According to him, creativity means a life attitude "to buy cheap and to sell expensive". He believes that creative thinking can be taught as taught mathematics and reading.

Complementary relationships between two thinking types lay at the heart of any creative process. Creativity requires only perception of the reality as it is, but this perception must be organized into a certain system, i.e. it must pass the initial stage of insight and include logical and verbal thinking.

The main characteristic of creativity is development of something new. A creative process depends on:

- a perceptual level of reflection;

- neural mechanisms of a mnestic informative level of reflection (formation of memory traces in the lower temporal lobe of the cerebral cortex);

- a semantic level of reflection.

New information is obtained through restructuring of relevant sensory information and it is manifested in super-consciousness (Simonov, 1987).

During relative rest, creative people's brain is activated more strongly. This fact can be 


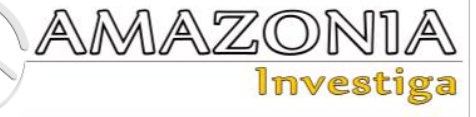

explained by greater sensory openness, greater sensitivity to slightest external stimuli of such people. The revealed difference in neuron and inter-neuronal connection distributions between the right and left temporal lobes is consistent with the difference of their functions. The most common tests for creative thinking confirm that contextual connections organized in a certain way are important for creativity.

Danilova (1995) and F. Gracham (1997) consider creative thinking as interaction of orientation and protective reflexes. Kholodnaya (2002) showed that talent correlated with depression and mental disorders, and Kunakh (2016) emphasized the correlation between creativity and neuroticism. These effects appeared probably because of feedback: during creative activities, the rational control over emotions is weakened.

Modern scientists apply two approaches to the nature of creativity. According to the first one, creativity is seen as an activity aimed at creating new socially significant values; the main attention is paid to the criteria of objective novelty and originality of creative products. The second approach connects creativity with human self-realization, with developed motivation for creativity. The creativity criterion, its value in this approach is a personality, not just creative products. Thus, creative activity can be characterized by the following parameters: a creating subject, a created result, and conditions for a creative process. There is no doubt that the centre of creativity, its basis is a personality, a subject, without whom a creative act is impossible. The general structure of creative activity as a system includes several main subsystems: a creative process; a product of creative acts; a creator; environment and conditions, in which a creative process takes place.

The divergent-convergent criterion assessing formed creative capabilities can be described as the subjective creativity parameter. The motivational-activity criterion corresponds to creativity results, and the personal-social criterion corresponds the conditions, in which a creative process takes place. As many studies have show, people with low and medium IQ have respectively low and medium creativity. People with high IQ can have either high or low creativity. People with high IQ and creativity are intensively studied by psychologists in the context of the problem of giftedness.

Adolescents with special educational needs have usually changed conditioned reflex activity, imbalance of excitation and inhibition processes, as well as disrupted interaction between the first and second signalling systems. All these physiological factors lead to an individual's abnormal mental development, affect negatively cognition, emotions, will and personality in general. Also self-doubt, have increased anxiety, irritability, emotional disorders; they experience significant lack of social contacts, face difficulties in interpersonal relationships, and have an increased need for protection. Responsibility for decision-making is often transferred to others, and their speech is dominated by the words: "loneliness", "inability", "failure", "futility of life". Such people have low self-esteem, self-doubt, do not believe in their self-realization, in particular in the personal sphere. Perception of adolescents with special educational needs is characterized by slow, reduced mobility of nervous processes, so the amount of material they can perceive is less.

Molyako (1978), analyzing creative processes, drew attention to the peculiarities of creative personality development in a social group, its dependence of group norms and values, especially in adolescence, which was also important for adolescents with developmental delay.

Children with special educational needs develop according to the same patterns as their peers with normal development. Physical and mental deficiencies are the ground for obstacles to communicative skill development and to social tie establishment; this is an unfavourable factor for personal development, disrupting normal socialisation (Vygotsky, 1968).

The most important oligophrenia symptom is insufficient intelligence, but adolescents with mild mental retardation are also characterized by impulsiveness, a tendency to obey someone else's will, a weak ability to purposeful activities, difficulties in differentiating subtle emotions, increased suggestibility, and deviant behaviour. Under specially organized education, adolescent with intellectual disabilities can develop significantly their emotional, volitional and intellectual spheres, namely: empathic skills can be formed, impulsivity can be reduced, and they start better control their behaviour. As a result of such correction, they become understand beautiful things, develop observation and meaningful memorization. Such positive influence on adolescents' emotional and volitional sphere promotes their higher spiritual qualities: conscience, devotion, sense of duty, 
responsibility, although these qualities are developed later compared to peers with normative development.

Emotional and social intelligence allows adolescents with intellectual disabilities to solve successfully problems in a familiar situation.

Therefore, we should note that studies on creativity and its formation is very important for quality corrective work with adolescents with intellectual disabilities and for their personality development, which help prepare them for life and future work.

\section{Methodology}

The creativity as an individual's trait should be examined comprehensively, because creativity includes many components, for example, artistic and aesthetic perception, creative imagination, intellect, general abilities, thinking and so on. Therefore, several research methods, including those proposed by J. Guilford (1967), R. Sternberg (2002), E.R. Torrance (1965), S. Beyer \& E.Bowden (1997) were developed to examine the above components, there are.

We used Davis (1969) method determining pupil's creative abilities as a personal trait and examining how creative abilities are formed at adolescents with intellectual disabilities. Davis' method determines creative abilities of 13-17 year old adolescents. The questionnaire contains 21 questions to examine creativity as a personal trait. Creativity includes: curiosity, selfsufficiency, a sense of harmony and beauty, altruism, risk acceptance, disorder acceptance, the need for activities. The method can be used by a psychologist together with a teacher once a semester. This method is used to evaluate effectiveness of applied programs and teaching methods, training materials and manuals. It is possible to monitor with this method changes in abilities, not just learning results.

\section{Results and Discussion}

Testing with the presented method was carried out in standard conditions of educational institutions (group form of testing); the sample consisted of adolescents with intellectual disabilities. Obtained raw data were processed with the method keys and analysed statistically. We should note that we examined adolescents with intellectual disabilities and the calculated indicators revealed adolescents' potential capabilities that must be fulfilled, which can be done, for example, with correctionaldevelopmental work developing these capabilities.

The experiment involved 172 adolescents (boy and girls) with moderate intellectual disabilities studying at special need school.

The obtained data were statistically processed using Student's t-test to compare mean values for subsamples (see Table 1).

Table 1.

Indicators of creativity depending on adolescents' gender and age

\begin{tabular}{lll}
\hline & Boys & Girls \\
\hline & 13 year old & \\
& $\mathrm{n}=32$ & $\mathrm{n}=23$ \\
Points & $9.93 \pm 0.26$ & $8.39 \pm 0.41$ \\
Creativity in \% & $47.32 \pm 1.5$ & $39.96 \pm 1.96$ \\
& 14 year old & \\
& $\mathrm{n}=36$ & $\mathrm{n}=27$ \\
Points & $13.19 \pm 0.48$ & $10.7 \pm 0.31$ \\
Creativity in \% & $62.83 \pm 2.29$ & $50.97 \pm 1.48$ \\
& 15 year old & \\
Points & $\mathrm{n}=29$ & $\mathrm{n}=25$ \\
Creativity in \% & $9.95 \pm 0.45$ & $10.7 \pm 0.41$ \\
\hline
\end{tabular}

According to the experimental data, it was found that creativity of 13-15-year old adolescents changed and it was developed in waves: increased firstly and decreased then. Thus, 13 year old respondents had creativity of $43.64 \%$. After a year (when the respondents reached 14 years), this indicator increased by $13.26 \%$, reaching the maximum $56.9 \%$, and declined again one year later and decreased by $7.69 \%$ to $49.21 \%$. Comparing 13-year old and 15-year old adolescents, their creativity increased by only $5.57 \%$ to 15 years, a wave-like jump was observed at 14 years (Fig. 1). 


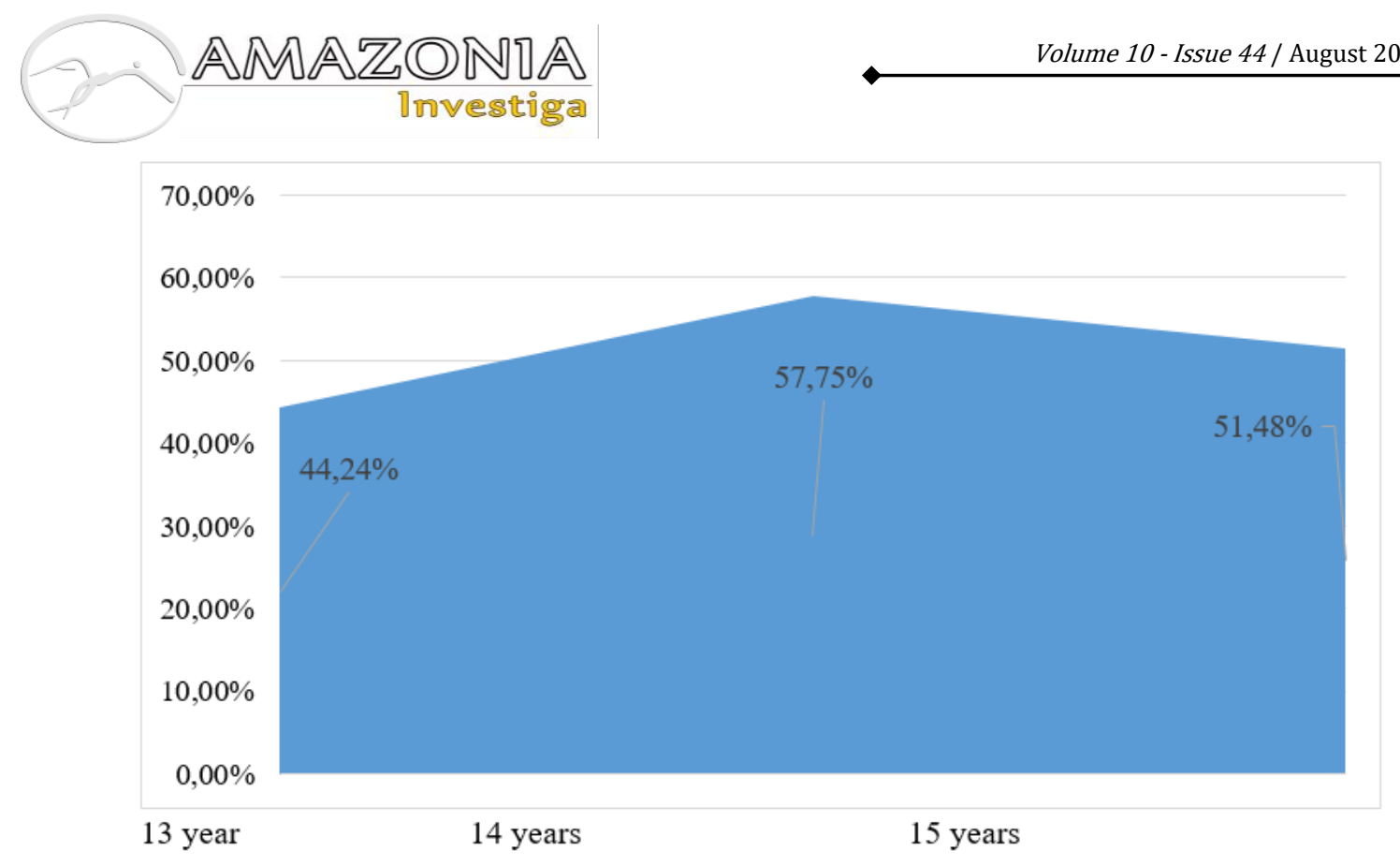

Figure 1. Creativity indicators depending on age

As for gender differences, boys' creativity was higher by $11.86 \%$ in comparison with girl's creativity and reaches $62.83 \%$ against $50.97 \%$.

If we take a closer look at relations creativity indicators with gender and age, we can see a significant lag in 13-14 year old girls' creativity, but later, to 15years girls' and boys' creativity becomes nearly equal (the difference is less than $1 \%$ ). The wavy jump, characteristic for 14 -yearold boys' creativity, turns to a drop by more than $24.6 \%$ during the last year. On contrast, girls show increased creativity to 14

year old, but after the growth almost stops, increasing by only $0.14 \%$ compared to 14 years.

The indicators on Figs. 2 show actual levels of creativity at 13 and 15 year old adolescents, so creativity can be examined at different stages. If we do not take into account creativity jump in 14year-old boys, but examine only differences between 13 and 15 years, we can draw the following conclusions: 13-year-old girls' creativity is lower by $15.56 \%$ compared to the same age boys, but girls' creativity increases by $21.7 \%$ up to 15 years. As for boys, their creativity grew only by $7.36 \%$, which is $14.01 \%$ lower in comparison with girls' creativity rise.

The obtained data show that more than half respondents had average creativity $(58.48 \%)$, a third of them had low creativity $(32.16 \%)$ and almost $10 \%$ of the respondents (16 adolescents from the entire sample) showed high creativity $(9.36 \%)$.

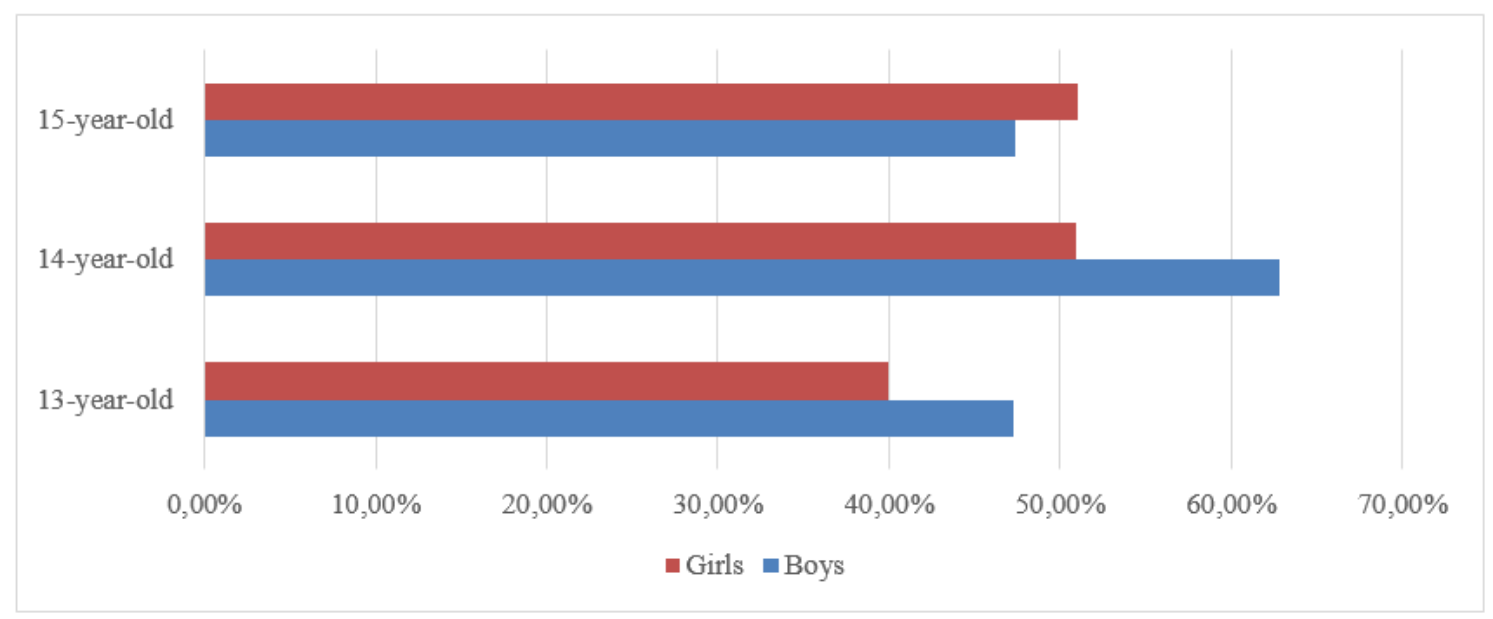

Figure 2. Adolescents' creativity depending on their gender and age. 
However, because this method say the creative abilities have only respondents scoring from 15 to 21 points (or $71.43-100 \%$ ), we can assume that 155 out of 172 adolescents, or $90.64 \%$ of the total sample, had low creative abilities, and only 16 students $(9.36 \%)$ showed really existing creative abilities.

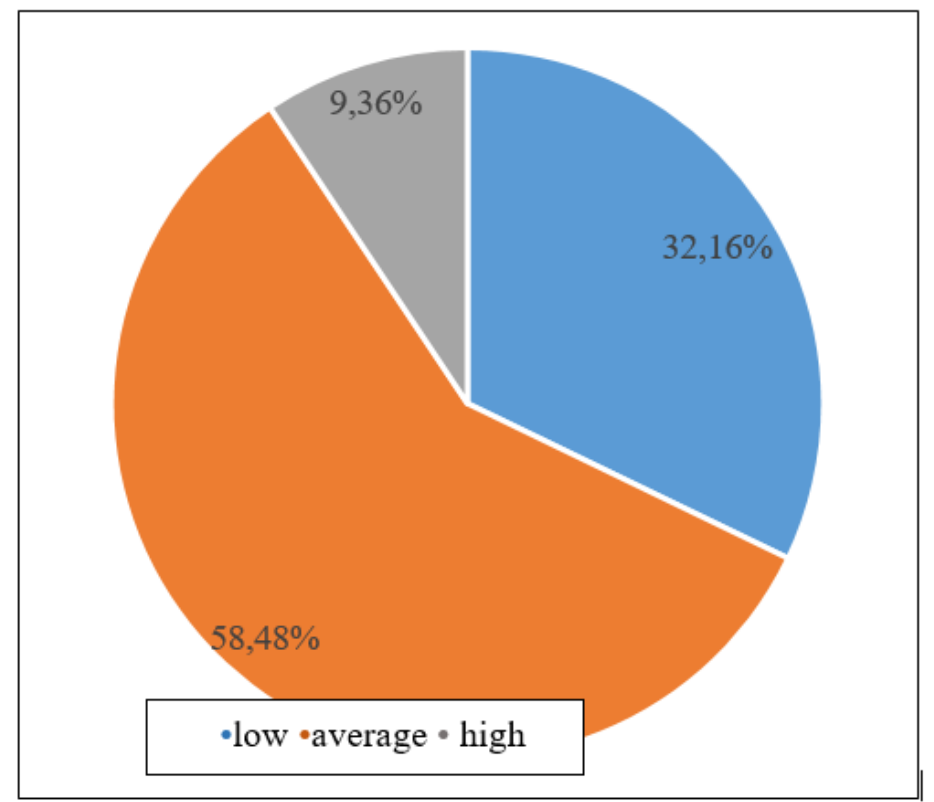

Figure 3. Distribution of studied adolescents by creativity formation.

\section{Conclusions}

1. The performed experimental study showed that $58.48 \%$ of the respondents had average creativity.

2. As for gender differences, 13-year-old boys' creativity was higher than that of the same age girls, creativity increased to 14 years and decreased again to 15 .

3. Girls' creativity increased gradually and was the highest at the age of 15 . A significant jump was observed from 13 to 14 years.

4. The obtained results indicate the need for correctional-developmental work with adolescents with intellectual disabilities; such work should be aimed at overcoming increased selfishness, emotional vulnerability, unresolved personal problems, romanticism, etc. by organization of creative activities.

\section{Bibliographic references}

Beyer, S., \& Bowden, E. M. (1997). Gender differences in self-perceptions: Convergent evidence from three measures of accuracy and bias. Personality and Social Psychology Bulletin, 23(2), 157-172. https://doi.org/10.1177/0146167297232005
Danilova, N.N. (1995). Heart rate and information load. Vestnik Moskov skogo universiteta. Ser. 14. Psychology, No 2, 14-18. Recovered from https://istina.msu.ru/publications/article/221 1833/

Davis, G.A. (1969). A program for training creative thinking: I. Preliminary field test. Recovered from https://files.eric.ed.gov/fulltext/ED036019.p df

Gracham, F. K. (1997). Afterword: Pre-attentive processing and passive and active attention. Attention and orienting: sensory and motivational processes. (pp. 417-452). Mahwah, NJ, US: Lawrence Erlbaum Associates.

Guilford, J.P. (1967). The Nature of Human Intelligence. McGraw-Hill Education

Karpenko, L.A., Petrovsky A.V., \& Yaroshevsky, M.G. (1985). A brief psychological dictionary. Moscow: Politizdat. Recovered from https://www.phantastike.com/common_psyc hology/brief_psy_dictionary/pdf/

Kholodnaya, M.A. (2002). Psychology of intelligence: paradoxes of research. 2nd ed., reworked and add.St. Petersburg: Piter. Recovered from http://www.intellectinvest.org.ua/content/userfiles/files/library/H olodnaya_Psihologiya_intellekta.pdf 


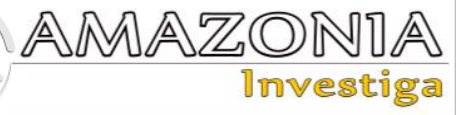

Khutorskoy, A.V. (2003). Didactic heuristics: Theory and technology of creative learning. M.: Publishing house of Moscow State University. ISBN 5-211-04710-9. Recovered from https://method.ucoz.ua/_ld/0/72 _.doc

Kondratieva, N.V. (2015). The essence of the concept of "creative abilities". Kontsept$2015 . \quad$ Recovered from https://cyberleninka.ru/article/n/suschnostponyatiya-tvorcheskie-sposobnosti

Kunakh, G.I. (2016). Creative ability development for children with special needs by the means of decorative and applied arts. Methodical manual. Vinnytsia: MMK. Recovered from https://www.google.com/url?sa=t\&rct=j\&q= \&esrc $=$ s \&source $=$ web $\& c d=\&$ ved $=2$ ahUKE wiAts7j2ePyAhVfhfOHHYp1CWkQFnoEC AcQAQ\&url=https\%3A\%2F\%2Fdorobok.e du.vn.ua\%2Ffile\%2Fget $\% 2$ F1379\&usg=AO vVaw12UnmBcW90_fKBy9mbgpwF

Leontiev, A.N. (1975). Activity. Consciousness. Personality. M.: Politizdat.

Molyako, V.A. (1978). Psychology of creative activity. Kiev: Knowledge. Recovered from https://pidru4niki.com/14860110/psihologiy a/molyako_psihologiya_tvorcheskoy_deyate lnosti
Nemov, R.S. (2003). Psychology. Book. 1 General principles of psychology. Moscow: Humanist. ed. center VLADOS.

Pavlov, I.P. (1951). Full composition of writings. Second revised edition. Tom II, kn. 2. M.-L.: Publishing house of the Academy of Sciences of the USSR.

Rusalov, V.M., \& Golubeva, E.A. (1980) Psychophysiological studies of intellectual self-regulation and activity: a scientific publication. M: Nauka.

Simonov, P. (1987). The motivated brain. Moscow: Nauka.

Stanislavsky, K.S. (2015). The actor's work on himself in the creative process of experience. M: Alphabet. Recovered from http://www.etnolog.org.ua/pdf/ebiblioteka/mystectv/teatr/stanislavskyi/tom2. pdf

Sternberg, P. (2002). Practical intelligence. St. Petersburg: Piter.

Torrance, E.P. (1965). Rewarding Creative Behavior. Experiments in Classroom Creativity. Englewood Cliffs, N. J.: PrenticeHall.

Turinina, O.I. (2007). Psychology of creativity: textbook. Kyiv: MAUP.

Vygotsky, L.S. (1968). Psychology of art. Moscow: Izd-vo APN SSSR. 